\title{
Argumentative Essay in the Perspective of Toulmin's Model: Needs of Evoluting Indonesian Society from Spoken Culture to Written Culture
}

\author{
Y Setyaningsih ${ }^{1}$, R K Rahardi ${ }^{2}$ \\ ${ }^{1,2}$ Master Program of the Indonesian and Literature Education, Sanata Dharma University, \\ Yogyakarta, Indonesia \\ E-mail: yulia@usd.ac.id
}

\begin{abstract}
The low quality of argumentations in argumentative essays should become the crucial concern of Indonesian scholars. This is due to the low understanding of the essay structure and the sharpness of the argument. Besides, this is also due to the long lasting spoken culture instead of written culture owned by most members of Indonesian society. The pressing needs of evoluting members of society to the right side of culture are thus very essential to be fulfilled. Therefore, it is deemed very necessary for the researchers to develop appropriate strategies to improve the quality of argumentative essay writing. This research is a preliminary study of a more rigorous development study. The source of the data for this study was argumentative essays written by students. The data was gathered by employing an observation method. Further, for the data analysis, the researchers were employing the distributional method and the content analysis. The research results showed that the essay structure as well as the arguments' sharpness should be improved. The description of the quality of the structure as well as the sharpness of the arguments was elaborated in the discussion part of this paper. The research results also highlight the researchers to design strategies to improve the quality of argumentative essays, and to trigger Indonesian society's evolution towards the qualified written culture, switching from the very long lasting spoken culture.
\end{abstract}

Keywords: Argumentative Essay; Argument Sharpness; Written Culture; Spoken Culture

\section{INTRODUCTION}

The ability to write argumentative essays cannot be separated from the ability to write argumentative paragraphs. It is concluded that way because the argumentative paragraph is 
really fundamental to enter an argumentative essay. The low quality of argumentations in argumentative essays cannot be separated from the low understanding of the essay structure and the sharpness of the argument. This is also due to the fact that spoken culture is more dominant than written culture in most members of Indonesian society [1].

Further, it can be asserted that the argumentative paragraph is intended to convince the reader of the argument that is conveyed by the writer. Whereas argument as citied in Ibrahim et al [2] is defined as "to attempt to persuade by giving good reasons is to give an argument". They further mention that the writer's confidence will be established only if the arguments conveyed by the writer are reliable and valid. In Toulmin's perspective, the reliability and validity of the argument can only be made if the claim statement as the main component of the argument is present correctly and appropriately.

In general, good argument is basically understood as having two sides, i.e. claim and counterclaims. Argumentative writing such as essay writing is understood as the process of making a claim, challenging a claim, supporting a claim with reasons. Besides, the writer also questions the reasons, rebutted them, and finally reaches a conclusion. Whereas Toulmin, Rieke, and Janik (1979) propose a similar model of argumentative writing that includes evidence, claim, warrant, backing, and rebuttal[3]. It is thus in line with Setyaningsih and Rahardi [4], that an argumentative writing absolutely must have a claim statement. Without the presence of a proper claim statement, it is impossible for a writing to be a correct argumentative writing. Claim statements can be present in various forms. The various manifestations of claim statement further result in models of argumentation as described by Douglas Walton[5] and elaborated by Setyaningsih and Rahardi [6].

It is generally understood that claim statements, or those in the discourse so far referred to as topic sentences, are usually subjective or even highly subjective. In fact, the subjectivity of claim statements or topic sentences should be lowered to the point of near objective. It is because the essence of a scientific writing is a work that has a high level of objectivity. Therefore, data or facts are needed to support the formulation of the claim statement. Such data or facts in argumentative writings can have double roles. On one hand, the data or facts can be used as the basis for the formulation of claim statements; on the other hand, the data or facts can also be used to support the formulation of the claim statements. Therefore, it can be asserted that data or facts are components that must be present after the aforementioned component, i.e. claim statement. Toulmin understands the data as one of the aspects of the grounds, which are fully stated as follows, "These are the author's reasons for WHY he/she is arguing her perspective. This includes evidence to also support his/her view on the issue" [7].

A correct argumentative text should also include warrant components after claim and data or fact statements. Warrant is an expert statement that is related and relevant to the claim statement proposed by the writer. With the presence of such warrant, the claim statement will degrade its' subjectivity level so that it will approach the objectivity. As pointed out earlier, the writer's personal argument cannot become the primary parameter of the scholarship of a work. Only when the personal arguments are based on relevant data that are concrete, clear and supported by the viewpoint of experts as a reference, such personal argument will decrease the subjectivity level to become an objective ones. The three basic components of the argument presented above must be present in an argumentative text. In other words, the three aforementioned components are the fundamental components that must always be sought by any argumentative writer. 
In Toulmin's perspective, there are still three additional components other than those presented above, namely the backing component, the modalities description, and the rebuttal as described by Setyaningsih and Rahardi [4]. The additional three components are not necessarily present in an argumentative text, but if the writer could present them in the text, the quality of the argumentative writing will be better. The backing element in the argumentative writing support the existence of the claim. It also has relationship with the data, but the closest relationship is not with data but with the claim. In addition to the above elements, rebuttal also constitutes additional element of argument functioning as the counter claim. Therefore the existence of rebuttal is to sharpen the claim. Where necessary, the description of modalities is also superseded in the writing of arguments.

In relation with essays, Kalidjernih [8] proposes several things. The first is the concept of an essay with a five-point construction. The second is the essay components which include an introductory paragraph that consists of statements which begin the thesis statement and the formulation of the thesis statement itself, three content paragraphs in which each paragraph's beginning starts with a topic sentence or position statement to describe the thesis statement in the introductory paragraph, and the last is a concluding paragraph containing the affirmation of the thesis statement that has been proposed at the beginning of the essay.

The thesis statement contained at the end of the introductory paragraph is also called the controlling idea. This controlling idea is the topic that is elaborated further into the paragraphs of the body of the essay. The thesis statement must have three criteria, namely (1) is a complete sentence, (2) expresses opinions, attitudes, and ideas, and (3) expresses only one idea [8]. The next essay component is a component of body paragraphs, which typically consists of three paragraphs. The three paragraphs of the body of the essay have to be a description of the thesis statement proposed in the introductory paragraph. Each paragraph must begin with a topic sentence which must be clearly defined and described in detail in one complete paragraph. Therefore, the paragraph must meet the requirement of coherence and cohesion.

A paragraph beginning with a topic sentence must be a comprehensive and complete paragraph; there should be no single fragment of ideas that are not elaborated in that paragraph. The next two paragraphs that follow also have to begin with a topic sentence and accompanied by explanatory sentences, both major or minor explanatory. Where necessary, each paragraph may end with a clarifying sentence to ensure that each paragraph has a complete, single, and unified explanation. The last component in an argumentative essay is a component of conclusion. The fifth paragraph of an argumentative essay should be a conclusion paragraph. The paragraph should conclude or reaffirm the explanations that have been proposed in the body paragraphs of the essay. In addition to the conclusion, which is included at the beginning of the last paragraph, a closing paragraph or a conclusion paragraph also ends with some final comments. The final comment presented at the end of the closing paragraph is what will build the impression about what has been described in previous sections [8].

The understanding of argumentative essay structure as stated by some experts in the above sections is very essential to the argumentative essay writers. The failure to understand comprehensively the structure of the argumentative essay will lead them to the low quality of arguments. The degree of sharpness of the arguments cannot be separated from the comprehension of these aspects. One very important thing that must also be noticed is the the aspects of culture, i.e. the written culture of the Indonesian society. The writing culture of the people tend to be relatively low, and the impact is that they do not pay much attention to the structure and sharpness of arguments [7]. 


\section{METHOD}

As explained in the introduction, the objective of this study is to improve the quality of student argumentative essay writing. To achieve the objective, the research team applies a qualitative descriptive approach. The research data are excerpts from sections of essays that contain arguments in both the introductory paragraph and the body paragraphs which constitute the contents of essays.

Thus, the source of data in this research is students' argumentative essays containing arguments in the introductory paragraph and body paragraphs. The method of data collection is observation, which involves a note taking technique, namely by listening to argumentative essays and recording the parts that contain arguments, especially in the introductory paragraphs and body paragraphs. The steps of data collection include (1) identification of arguments, (2) inventory of arguments, (3) selection of arguments, and (4) classification of arguments. Meanwhile, the data analysis method was a distributional method by the segmenting immediate constituents technique. The methods and techniques of data analysis are carried out by interpreting data in the form of arguments from the introductory paragraphs and body paragraphs.

\section{RESULT AND DISCUSSION}

In this discussion section, two argumentative essays are presented from a course module compiled by the students entitled "Kata Kami". The two essays were analyzed in accordance with the standards related to the development of correct argumentative essays. The analysis of these two essays becomes a very important part of the development research phase that will be carried out by the research team related to the argumentative essay writing model. The title of the first essay is Pentingkah Peranti-peranti Diksi dalam Tulisan - The Importance of Diction Devices in Writing whereas the title of the second essay is Paragraf yang Baik, Membuat Pembaca Tertarik - Good Paragraphs Interest Readers. The detail discussions of both essays can be seen in the following section.

Data 1. Introductory Part

\begin{tabular}{|c|c|c|}
\hline Component & Indonesian Text & English Text \\
\hline $\begin{array}{l}\text { Essay } \\
\text { Introductory } \\
\text { Part }\end{array}$ & $\begin{array}{l}\text { Sejumlah orang menganggap mudah } \\
\text { membuat tulisan fiktif maupun } \\
\text { ilmiah, tetapi banyak orang yang } \\
\text { menganggap sulit. Kemudahan } \\
\text { membuat sebuah tulisan baik tidak } \\
\text { menjamin tulisan itu bernilai baik. } \\
\text { Agar tulisan itu baik, seseorang } \\
\text { yang hendak menulis perlu } \\
\text { memperhatikan beberapa peranti } \\
\text { pemilihan kata (diksi) berikut ini. }\end{array}$ & $\begin{array}{l}\text { [Some people find it easy to make } \\
\text { both fiction and scientific writing, } \\
\text { but many others find it difficult. The } \\
\text { ease of making a good writing does } \\
\text { not guarantee the quality of the text. } \\
\text { In order to make a good text, } \\
\text { someone who wants to write needs to } \\
\text { pay attention to some of the } \\
\text { following word selection devices.] }\end{array}$ \\
\hline
\end{tabular}


The formulation of the title "Pentingkah Peranti-peranti Diksi dalam Tulisan - The Important of Diction Devices in Writing" already implies that the accompanying text is an argumentative text about whether or not diction devices are important in a writing. However, the title is not manifested in a concrete formulation of the thesis statement at the end of the introductory paragraph that reads, "In order to make a good text, someone who wants to write needs to pay attention to some of the following word selection devices (diction)." In accordance with the standards, the formulation of the thesis statement should be a statement of attitude, idea, or opinion of the writer.

However, the formulation of the thesis statement does not indicate the statement of attitude as it has been expressed in the title. Although the formulation of the thesis statement could be considered to have contained the ideas or opinions of the writer, yet the use of the term "following" at the end of the formula indicates that the description details will follow the statement of the thesis. The above description can be seen in the following table.

Data 2. Body Part

\begin{tabular}{|c|c|c|}
\hline Component & Indonesian Text & English Text \\
\hline $\begin{array}{l}\text { Essay } \\
\text { Body Parts }\end{array}$ & $\begin{array}{l}\text { Peranti kata berdenotasi dan } \\
\text { berkonotasi. Peranti kata berdenotasi } \\
\text { tidak mengandung makna tambahan, } \\
\text { misalnya kursi yang diletakkan di } \\
\text { dalam sebuah ruangan. Kata tersebut } \\
\text { langsung menunjuk pada sebuah benda } \\
\text { yang dipakai untuk duduk. Kata yang } \\
\text { bermakna denotatif lazimnya dipakai } \\
\text { dalam karya-karya jurnalistik dan } \\
\text { karya-karya ilmiah akademik. } \\
\text { Sedangkan peranti kata berkonotasi } \\
\text { mengandung makna tambahan, } \\
\text { misalnya kursi yang sering } \\
\text { diperebutkan oleh para calon anggota } \\
\text { DPR. Kata tersebut menunjuk pada } \\
\text { jabatan. Makna konotatif cenderung } \\
\text { digunakan pada situasi tidak formal } \\
\text { yang membutuhkan basa-basi, dan } \\
\text { membutuhkan bentuk-bentuk } \\
\text { kesantunan yang tinggi. }\end{array}$ & $\begin{array}{l}\text { [Diction devices denotate and } \\
\text { connote. Denotation diction device } \\
\text { means the word has no additional } \\
\text { implied meaning, such as the chair } \\
\text { is placed in a room. The word } \\
\text { directly points to an object used for } \\
\text { sitting. Denotative words are } \\
\text { commonly used in journalistic and } \\
\text { academic scholarly works. } \\
\text { Meanwhile, connotative work } \\
\text { device contains additional implied } \\
\text { meaning, for example the } \\
\text { candidates of members of } \\
\text { Parliament often contest a chair. } \\
\text { The word refers to the position. The } \\
\text { connotative meaning tends to be } \\
\text { used in informal situations that } \\
\text { require courtesy and require high } \\
\text { forms of politeness.] }\end{array}$ \\
\hline & $\begin{array}{l}\text { Peranti kata bersinonimi dan } \\
\text { berantonimi. Kata bersinonimi berarti } \\
\text { dua kata atau lebih yang mempunyai } \\
\text { arti yang sama, misalnya hamil dan } \\
\text { bunting. Seorang yang hendak menulis }\end{array}$ & $\begin{array}{l}\text { [Diction devices that are } \\
\text { synonymous and antonymous. } \\
\text { Synonymous word means two or } \\
\text { more words that have the same } \\
\text { meaning, such as pregnant and }\end{array}$ \\
\hline
\end{tabular}


seharusnya memiliki perbendaharaan kata bersinonim supaya memudahkan penulisan suatu karya tulis. Sedangkan kata berantonimi berarti dua kata atau lebih yang mempunyai makna berlawanan, misalnya hitam dan putih. expectant. A person who wants to write should have vocabulary of synonym in order to facilitate the process of writing. Meanwhile, antonym word means two or more words that have opposite meanings, such as black and white.]

Peranti kata konkret dan abstrak. Peranti kata konkret merupakan peranti kata yang dapat diindrai, misalnya meja, kursi, kertas. Kita dapat langsung melihat dan meraba bendabenda itu. Kata-kata konkret lazim dipakai untuk deskripsi dan beberapa juga untuk narasi. Sedangkan peranti kata abstrak menunjuk pada konsep atau gagasan, misalnya pendidikan, kemiskinan, pembodohan. Kata-kata abstrak biasanya dipakai untuk membuat persuasi dan atau argumentasi.

Peranti kata umum dan kata khusus. Peranti kata umum perlu dijabarkan lebih lanjut dengan kata-kata yang sifatnya khusus untuk mendapatkan perincian yang lebih baik, misalnya lihat, jatuh. Kata-kata demikian lebih tepat digunakan untuk argumentasi, atau persuasi. Sedangkan peranti kata khusus ruang lingkupnya sempit, misalnya melirik, terpeleset. Dalam karya-karya ilmiah yang perlu akurasi dalam pendeskripsian dan penjelasan, peran kata-kata yang sifatnya khusus demikian akan menjadi besar dan signifikan.
[Concrete and abstract diction devices. A concrete word is an observable word device, such as a desk, chair, and paper. We can directly see and feel the objects. Concrete words are commonly used for description and some are for narration. Meanwhile, the abstract word refers to concepts or ideas, such as education, poverty, and duping. Abstract words are usually used to create persuasion and/or argumentation.]

[General and specific diction devices. General word tool needs further elaboration with more specific words of a particular nature to get better details, such as see and fall. Such words are more appropriate for argumentation or persuasion. Meanwhile, specific word has narrower scope, such as glance and slip. In scientific works that need accuracy in descriptions and explanations, the role of words of such particularity will be great and significant.] 


$\begin{array}{ll}\text { tegas, lurus, tidak berbelit-belit, } & \text { penis and coitus. This devide is used } \\ \text { misalnya zakar, senggama. Peranti ini } & \text { to analyze research data and draw } \\ \text { digunakan untuk menganalisis data } & \text { conclusions in research. Meanwhile } \\ \text { penelitian, menarik simpulan dalam } & \text { for indirect word tool, for example } \\ \text { penelitian. Sedangkan peranti kata } & \text { the word commercial sex workers } \\ \text { bernilai rasa, misalnya kata pekerja } & \text { have more valuable taste than the } \\ \text { seks komersial yang lebih bernilai rasa } & \text { word prostitutes. Indirect word } \\ \text { daripada pelacur. Peranti kata bernilai } & \text { tools are often used in casual } \\ \text { rasa sering dipakai dalam tulisan yang } & \text { writing as in letters.] }\end{array}$

sifatnya santai seperti dalam surat.

From the excerpt of the above paragraphs in the essay body, it is found that no paragraph begins with a topic sentence which Toulmin suggests as a claim statement [9]. The topic sentence is also not elaborated into major and minor explanatory sentences. The explanatory sentences should contain experts' views, generally accepted rules (warrants), or similar studies (backing) which all support and reinforce the existence of the claim statement. The paragraphs in the essay body above will become better if they include a rebuttal element so that the claim statement gets stronger. Where necessary, the paragraphs should also include a description of modalities. The presence of the modalities statement will further emphasize the claim statement as it refers to the degree of certainty of a claim statement. The table below summarizes the above description.

Data 3. Closing Part

\begin{tabular}{|c|c|c|}
\hline Component & Indonesian Text & English Text \\
\hline $\begin{array}{l}\text { Essay } \\
\text { Closing Part }\end{array}$ & $\begin{array}{l}\text { Pemilihan kata yang tepat sesuai dengan } \\
\text { jenis peranti-peranti seperti itu dapat } \\
\text { membuat sebuah tulisan bernilai baik. } \\
\text { Akhirnya orang lain yang membaca pun } \\
\text { mudah menangkap maksud dari tulisan } \\
\text { itu dan tertarik untuk membacanya. }\end{array}$ & $\begin{array}{l}\text { [Choosing the right words } \\
\text { according to the type of diction } \\
\text { device can make a better writing. } \\
\text { Finally, others who read it will } \\
\text { easily catch the intention of the } \\
\text { article and be interested to read } \\
\text { it.] }\end{array}$ \\
\hline
\end{tabular}

The thesis statement of this argumentative essay is "In order to make a good text, someone who wants to write needs to pay attention to some of the following word selection devices (diction)." The thesis statement is in line with the clarifying sentence contained in the closing paragraph. Therefore, it is indeed the construction of the closing paragraph.

It should contain a sentence that confirms the thesis statement in the introductory paragraph. It should not have exactly the same formulation of the thesis statement, but the substance of the sentence has to be the same. 
Data 4. Introductory Part

\begin{tabular}{|c|c|c|}
\hline Component & Indonesian Text & English Text \\
\hline $\begin{array}{l}\text { Essay } \\
\text { Introductory } \\
\text { Part }\end{array}$ & $\begin{array}{l}\text { Paragraf merupakan rangkaian dari } \\
\text { beberapa kalimat yang tersusun } \\
\text { secara runtut dan sistematis, } \\
\text { sehingga membentuk satu kesatuan } \\
\text { yang padu dan utuh. Hal ini mau } \\
\text { menunjukkan bahwa sebuah } \\
\text { paragraf harus mengandung } \\
\text { pertalian yanglogis antarkalimatnya } \\
\text { agar mampu menyampaikan } \\
\text { kesatuan pikiran/gagasan bagi } \\
\text { pembaca. Dengan demikian, } \\
\text { pertautan yang terjadi antara } \\
\text { kalimat yang satu dan kalimat yang } \\
\text { lainnya mengandaikan terjadinya } \\
\text { kepaduan dan kesatuan unsur-unsur } \\
\text { paragraf itu. Kesatuan dalam } \\
\text { paragraf inilah yang menjadi dasar } \\
\text { penyusunan sebuah karya ilmiah } \\
\text { akademis agar lebih berbobot dan } \\
\text { ide yang hendak disampaikan } \\
\text { menjadi jelas bagi yang } \\
\text { membacanya. }\end{array}$ & $\begin{array}{l}\text { [A paragraph is a series of several } \\
\text { sentences that are arranged } \\
\text { coherently and systematically, thus } \\
\text { forming a unity that is integrated } \\
\text { and complete. This would indicate } \\
\text { that a paragraph has to contain a } \\
\text { logical connection between them to } \\
\text { convey the unity of thoughts/ideas } \\
\text { to the reader. Thus, the link between } \\
\text { one sentence and the other } \\
\text { presupposes the integration and } \\
\text { completeness of the elements of that } \\
\text { paragraph. The unity in a paragraph } \\
\text { is the basis for the development of } \\
\text { an academic scientific work to have } \\
\text { better quality and the idea to be } \\
\text { conveyed becomes clear to those } \\
\text { who read it.] }\end{array}$ \\
\hline
\end{tabular}

In the introductory paragraph excerpt above, the formulation of the thesis statement is inconsistent with the rule of formulation of the correct thesis statement. There are two ideas contained in the thesis statement, whereas normatively a thesis statement contains one idea. It violates the rule because it contains two ideas. In addition, the formulation of a thesis statement that reads, "The unity in a paragraph is the basis for the development of an academic scientific work to have better quality and the idea to be conveyed becomes clear to those who read it" is not in accordance with the issues proposed in the title. The thesis statement should reflect the issues raised by the writer. The following table summarizes the above description

Data 5. Body Part

\begin{tabular}{lll}
\hline Component & \multicolumn{3}{c}{ Indonesian Text } & English Text \\
\hline Essay Body & $\begin{array}{l}\text { Ide utama atau ide pokok dalam } \\
\text { Parts }\end{array}$ & [The main idea or central idea in a \\
& seburagraf mutlak ada karena & paragraph should be present because
\end{tabular}




\begin{tabular}{|c|c|}
\hline $\begin{array}{l}\text { tkan menentukan wujud dari paragraf } \\
\text { tu. Paragraf yang tidak memiliki ide } \\
\text { okok, sesungguhnya tidak dapat } \\
\text { lianggap sebagai paragraf. Ide pokok } \\
\text { nilah pengendali dari bangunan } \\
\text { aragraf itu sendiri yang dikemas } \\
\text { lalam sebuah kalimat yang dapat pula } \\
\text { nenjadi kalimat utama atau kalimat } \\
\text { okok. Kalimat utama atau kalimat } \\
\text { okok ini bias terdapat di awal } \\
\text { aragraf (alur pikir deduktif), di akhir } \\
\text { aragraf(alur pikir induktif), di dalam } \\
\text { aragraf (alur pikir ineratif), dan juga } \\
\text { li awal dan di akhir paragraf (alur } \\
\text { ikir abduktif). Dari kalimat utama } \\
\text { tulah kalimat-kalimat penjelas, baik } \\
\text { ang bersifat mayor, minor, dan } \\
\text { ubminor, dituliskan secara tuntas, } \\
\text { engkap, dan terperinci. }\end{array}$ & $\begin{array}{l}\text { it will determine the form of the } \\
\text { paragraph. A paragraph that has no } \\
\text { main idea cannot really be } \\
\text { considered as a paragraph. The main } \\
\text { idea is the controller of the } \\
\text { paragraph form itself that is } \\
\text { formulated in a sentence that can } \\
\text { also be the main sentence or the } \\
\text { central sentence. This main or } \\
\text { central sentence can be located at the } \\
\text { beginning of the paragraph } \\
\text { (deductive thinking), at the end of } \\
\text { the paragraph (inductive thinking), } \\
\text { in the paragraph (inerative thinking), } \\
\text { as well as at the beginning and at the } \\
\text { end of the paragraph (abductive } \\
\text { thinking). From the main sentence, } \\
\text { the explanatory sentences - major, } \\
\text { minor, and subminor - are written } \\
\text { thoroughly, completely and in } \\
\text { detail.] }\end{array}$ \\
\hline
\end{tabular}

In the above paragraph of the essay body, only one paragraph is found. Therefore, it violates the rules of development of the correct argumentative essay. In accordance with the norm, an essay with a five-point construction should consist of three paragraphs. In addition, the substance of the paragraph in the body is inconsistent with the substance of the thesis statement that is marked by the non-existence of a topic sentence that describes the thesis statement. The statement of the thesis in the introductory paragraph reads, "The unity in a paragraph is the basis for the development of an academic scientific work to have better quality and the idea to be conveyed becomes clear to those who read it", while the topic sentence in the paragraph of the body reads, "The main idea or central idea in a paragraph should be present because it will determine the form of the paragraph." The above description is summarized in the next table.

Data 6. Closing Part

\begin{tabular}{llll}
\hline Component & Indonesian Text & English Text \\
\hline Essay & Maka, paragraf yang baik ialah & [Therefore, a good paragraph is a \\
Closing Part & paragraf yang memungkinkan & paragraph that allows the reader to \\
pembaca memahami kesatuan & understand the unity of the \\
& informasi yang terkandung di & information contained in it. A \\
dalamnya. Paragraf juga dapat & paragraph can also be considered \\
dikatakan baik apabila gagasan & good if the controlling idea that \\
\hline
\end{tabular}




pokok (controlling idea) yang
mengendalikan paragraf itu sudah
sepenuhnya dikembangkan dan
tuntas diuraikan. Jadi, paragraf
yang baikitu tidakboleh menyisakan
serpihan gagasan yang terkandung
di dalam ide pokok paragraf itu
(Frank Chaplen). Dengan demikian,
setiap orang diajak agar mampu
memeranti diksi yang tetap,
menyusun kalimat yang efektif,
membuat resensi yang benar dan
tajam, dan mampu menulis karya
ilmiah akademik yang baik dengan
menggunakan bahasa Indonesia
yang baik dan benar serta dengan
memperhatikan tata tulis dan
ketentuan-ketentuan ejaan yang
berlaku.

guides the paragraph has been fully developed and thoroughly elaborated. Hence, a good paragraph should not leave any piece of ideas contained in the main idea of the paragraph (Frank Chaplen). Thus, everyone is invited to be able to utilize fixed diction, compose effective sentences, make correct and sharp reviews, and write good scientific work by using good and correct Bahasa Indonesia in accordance with the language rules.]

The results of the analysis of the argumentative essays as the preliminary research data suggested that the writers have not fully understood the correct essay structure with the threepart component, i.e. the introductory paragraph, the paragraphs of the body, and the closing paragraph. The writers also have not fully mastered the substance of the paragraphs of an argumentative essay [10]. It appeared, for example, in the development of the introductory paragraph. Normatively, the introductory paragraph should contain a sentence that draws the reader's attention and the sentence that becomes the thesis statement. However, these elements were not available in the essay introductory paragraphs observed by the research team. Likewise, the standards concerning the formulation of thesis statements were also violated. The research team found that the thesis statements made by the writers were not really correct thesis statements.

\section{CONCLUSION}

This preliminary study of the argumentative writings that have been conducted showed that the writer's ability to develop argumentative essays in Indonesia still needs to be improved. One attempt to improve the ability to write an argumentative essay can be done by developing a model of writing that takes into account the five-point principle and Toulmin's argumentative perspective. The development of an argumentative essay with five-point principle is very useful for learning to write essays with correct construction. The development of an argumentative essay with Toulmin's perspective is very useful for sharpening arguments in essay writing. The low quality of argumentations in argumentative essays should become the concern of Indonesian scholars. This is due not only to the low understanding of the essay structure and the sharpness 
of the argument but the long lasting spoken culture instead of written culture owned by most members of Indonesian society. The pressing needs of evoluting members of society to the right side of culture are thus very essential to be fulfilled.

\section{REFERENCES}

[1] D. Siepmann, "Academic Writing and Culture: An Overview of Differences between English, French and German," Meta J. des traducteurs, vol. 51, no. 1, p. 131, 2006.

[2] N. S. A. E. Hussein, I. B. Mohammed, and M. E. EIsafi, "To What Extent can Argumentative Essay Writing Help Develop Leaners' Critical Thinking,” J. Sci. Technol., vol. 16, no. 4, 2015.

[3] Y. W. Lam, K. F. Hew, and K. F. Chiu, "Improving Argumentative Writing: Effects of a Blended Learning Approach and Gamification," Lang. Learn. Technol., vol. 22, no. 1, pp. 97-118, 2018.

[4] Y. Setiyaningsih, "Peningkatan Kadar Ketajaman Argumen Paragraf-paragraf Argumentatif Artikel Jurnal dalam Perspektif Stephen Toulmin," in Seminar Internasional KOLITA 15, 2017, pp. 509-513.

[5] D. Walton, Methods of Argumentation. Cambridge: Cambridge University Press, 2013.

[6] Setyaningsih Y and R. R. K, "Argumentatif Literacy in Toulmin Perspective in Developing Argumentatif Paragraphs for Journal Article Writers with Various Cultural Background," in Prosiding ICELA: Intercultural Communication through Language, Literature, and Arts. Fakultas Bahasa dan Seni, Universitas Negeri Jakarta, 2017, pp. $1297-1310$.

[7] S. Toulmin, R. Rieke, and A. Janik, An Introduction to Reasoning. New York: Macmillan Publishers, 1979.

[8] F. K. Kalidjernih, Penulisan Akademik: Esai, Makalah, Artikel Jurnal Ilmiah, Skripsi, Tesis, Disertasi. Bandung: Widya Aksara Press, 2011.

[9] L. A. Rex, E. E. Thomas, and S. Engel, "Applying Toulmin: Teaching Logical Reasoning and Argumentative Writing," English J., vol. 99, no. 6, pp. 56-62, 2010.

[10] F. W. Otike, "Reading Culture, Cultivation and Its Promotion among Pupils," A Kenyan Perspect. Int. Res. J. Libr. Inf. Arch. Stud., vol. 1, no. 1, pp. 1-5, 2011. 